\title{
Development and validation of eDNA markers for the detection of Crepidula fornicata in environmental samples
}

\section{Laura- Miralles 1}

Marina -Parrondo $1^{-}$

Alma- Hernández de Rojasszạ

E-va Garcia-Vazquez $\underline{1}^{\underline{a}}$

Yaisel -Juan- Borrell $1^{\underline{a}}$ *

borrellyaisel@uniovi.es

ta-Department of Functional Biology, Genetics, University of Oviedo. C. Julián Clavería s/n\33006 Oviedo, Spain

${ }^{2 b}$ Spanish Institute of Oceanography, Oceanographic Center of Gijón, Avda. Príncipe de Asturias, 70 bis, 33212 Gijón, Spain

*Corresponding author.

\section{Abstract}

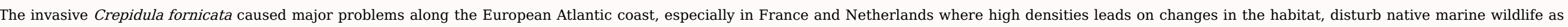

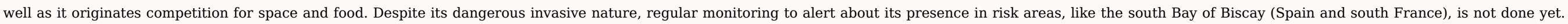

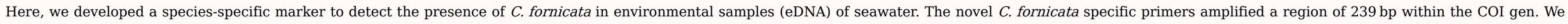

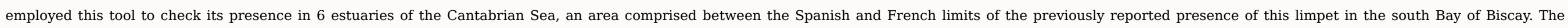

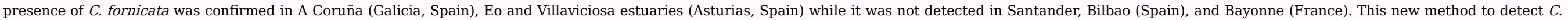
fornicata could be easily implemented in regular monitoring to prevent and manage future invasions of this species.

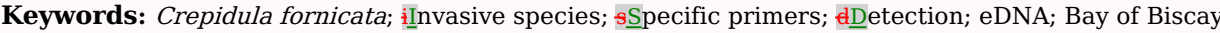

\subsection{Introduction}

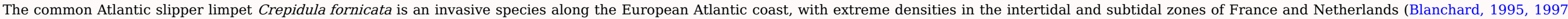

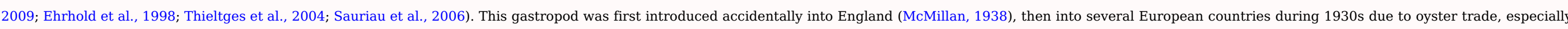

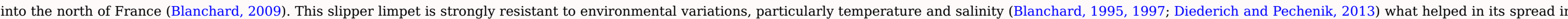

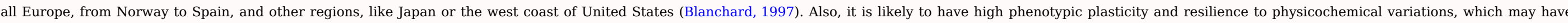

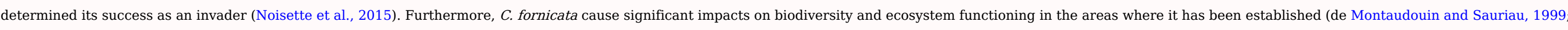

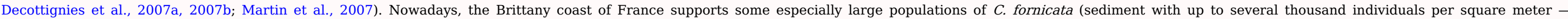

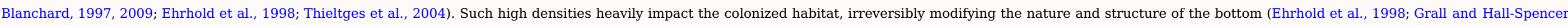

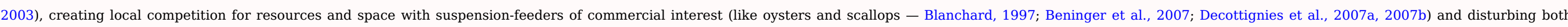

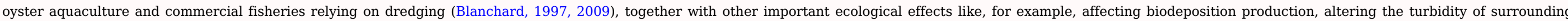

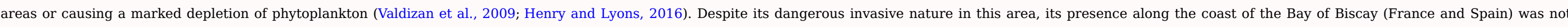

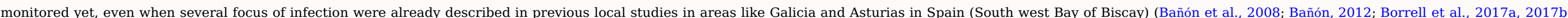




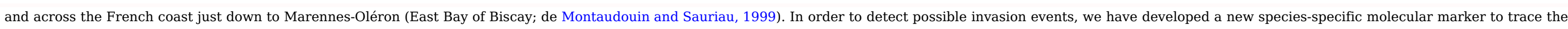
presence of $C$. fornicata in environmental DNA (eDNA) samples. Finally, we tested this new marker in different seawater samples from estuaries from the Cantabrian Sea in the South Bay of Biscay.

\subsection{Material and Mmethods}

\subsubsection{Sample acquisition and processing}

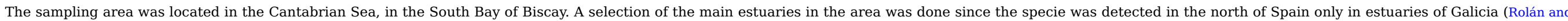

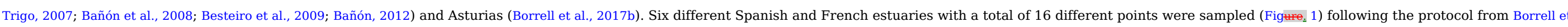

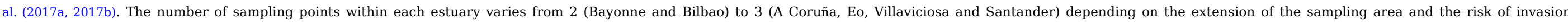

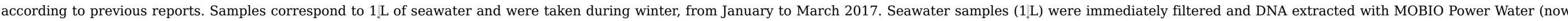

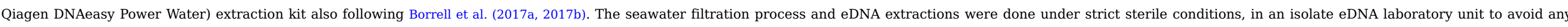

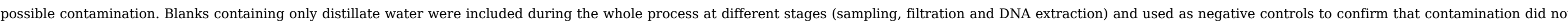
occur in the process.
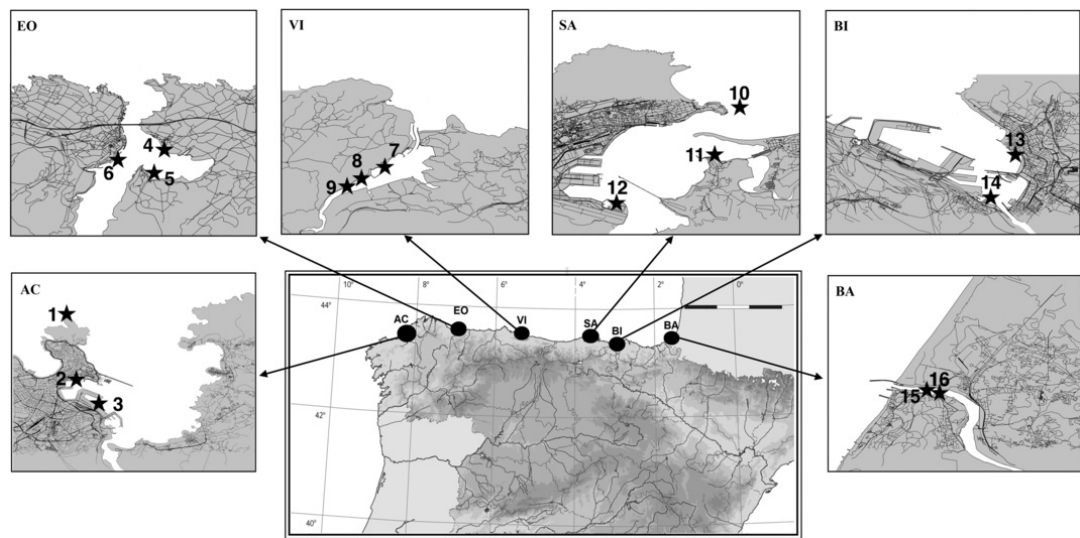

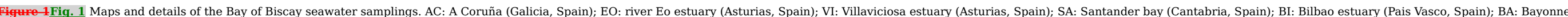
estuary (Anglet, France). Numbers correspond to different sampling points (1=16).

\section{alt-text: Fig. 1}

\subsubsection{Crepidula fornicata specific marker design and validation}

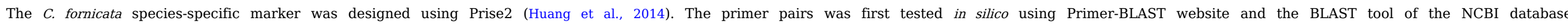

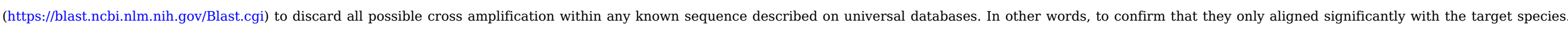

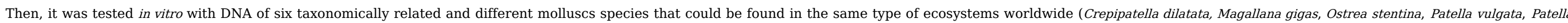

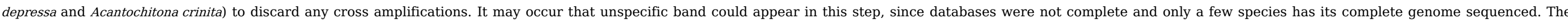

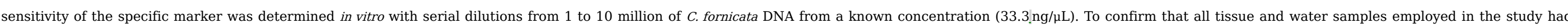
good DNA quality for amplification, the COI gene was amplified following Geller et al. (2013) to discard false negatives in the PCR.

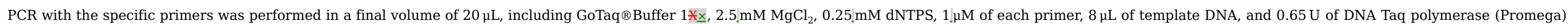

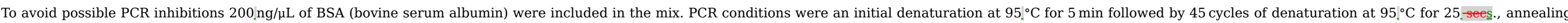

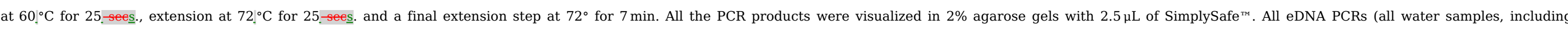




\section{3. $\underline{3}$ Results and discussion}

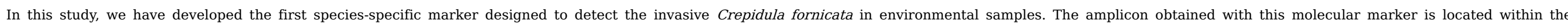
cytochrome oxidase subunit I (COI) gen using the primers sequences: Forward 5'-GATGATCAACTATACAATGTA-3"- and Reverse $5^{\prime \prime-}$ - TAAACCGTTCAACCGG-3"-

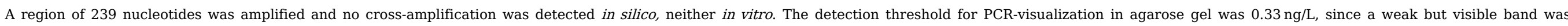

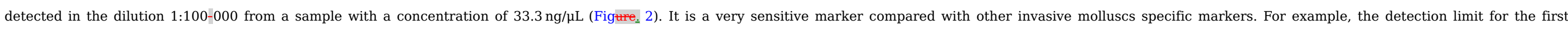

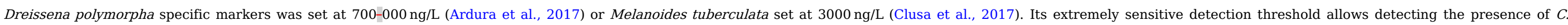

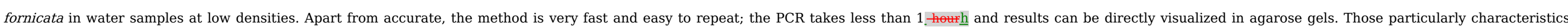

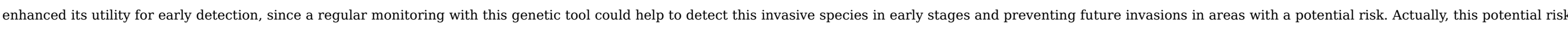
becomes a real fact in areas currently surrendered by $C$. fornicata invasive processes, like the Cantabrian Sea in the Bay of Biscay.

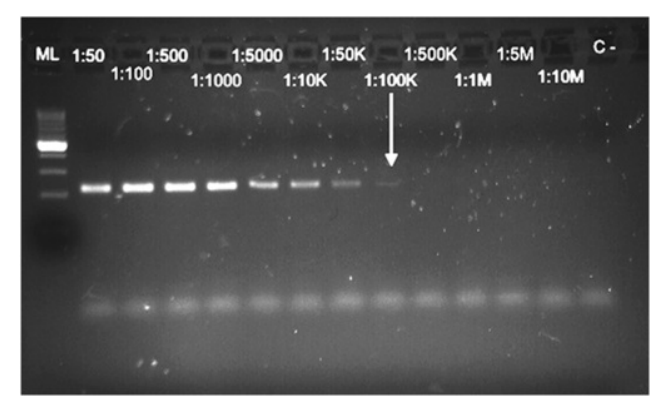

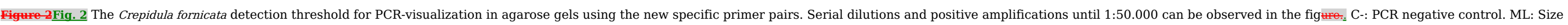
ladder (Perfect 100=1000 bp DNA Ladder from EurX).

\section{alt-text: Fig. 2}

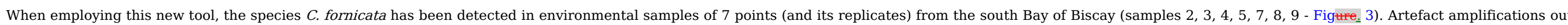

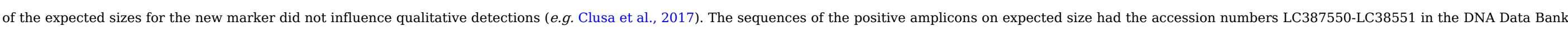

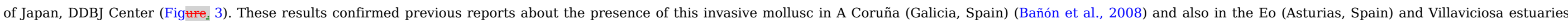

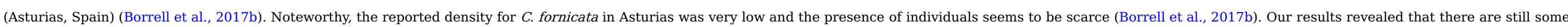

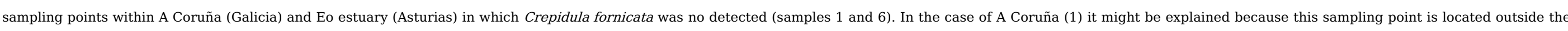

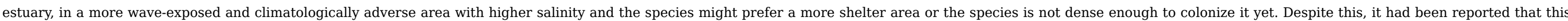

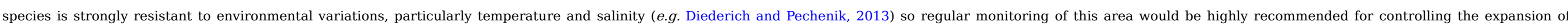

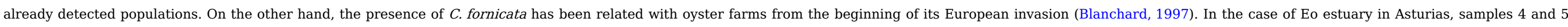

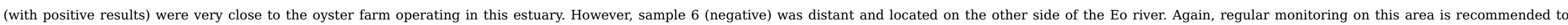

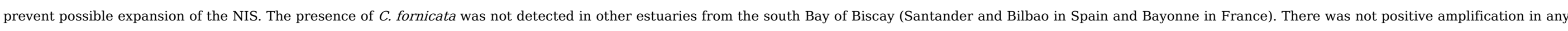
of its environmental samples (numbers 10-15 and its replicates; Figure, 3), neither previous references about its presence. 

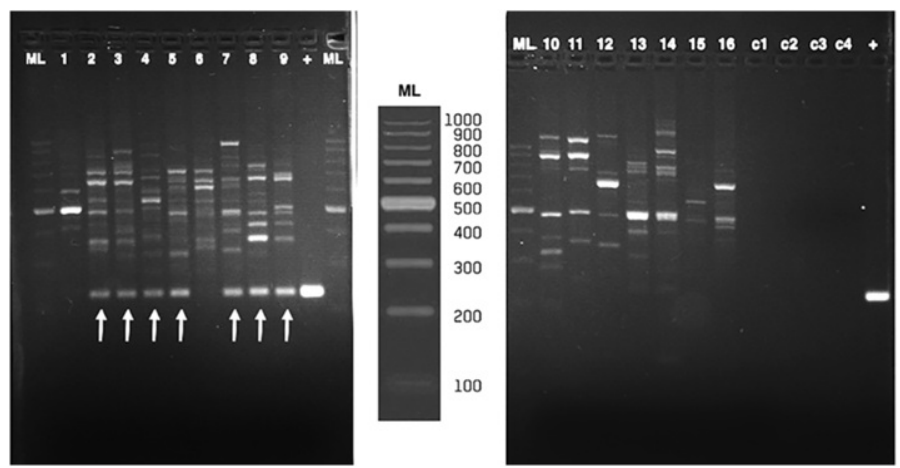

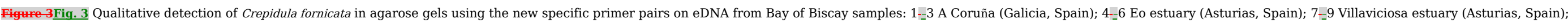

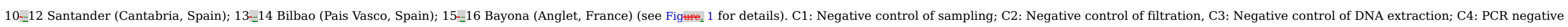
control; +: positive control of Crepidula fornicata dilution 1:100; ML: Size ladder (Perfect 100-1000 bp DNA Ladder from EurX).

alt-text: Fig. 3

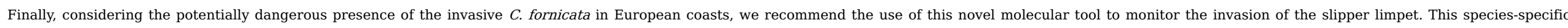

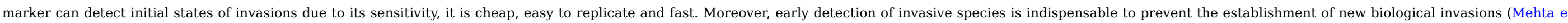

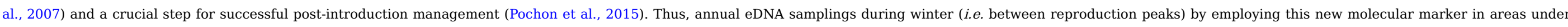
risk of introduction could be useful and would help to monitor, control and minimize the possibility of a new $C$. fornicata invasion.

\section{Acknowledgements}

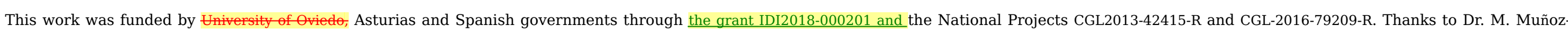

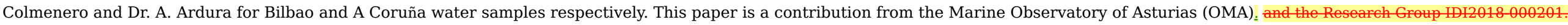

\section{References}

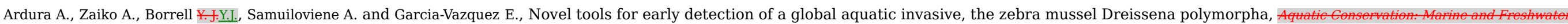
Eeosystems Aquat. Conserv. Mar. Freshwat. Ecosyst. 27 (1), 2017, 165-176.

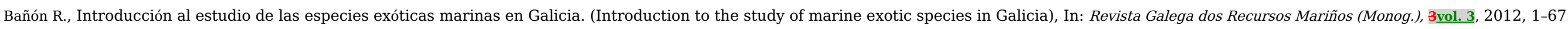

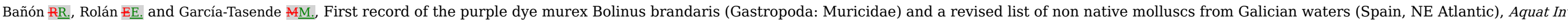
3 (3), 2008, 331-334.

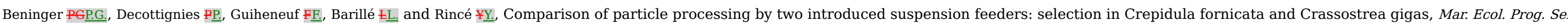
334, 2007, 165-177.

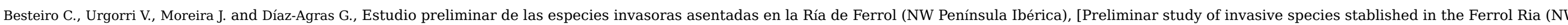
Iberian Peninsula)], In: 3o Congreso nacional sobre especies exóticas invasoras. Zaragoza, 24-27 noviembre de 2009, $2009,21$.

Blanchard ¥프., Origine et état de la population de crépidule (Crepidula fornicata) sur le littoral français, Haliotis 24, 1995, 75-86.

Blanchard M…, Spread of the slipper limpet Crepidula fornicata (L. 1758) in Europe. Current state and consequences, Sei Mar Sci. Mar. 61, 1997, 109-118.

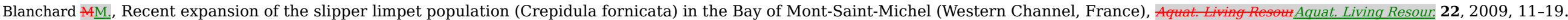




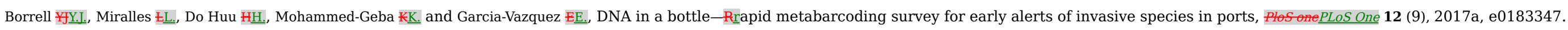

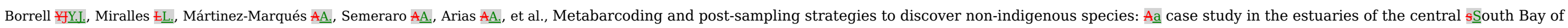
Biscay, Jat Conser. Nat. Conserv. 2017b, https://doi.org/10.1016/j.jnc.2017.07.002.

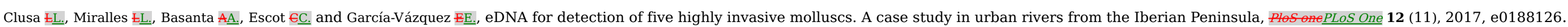

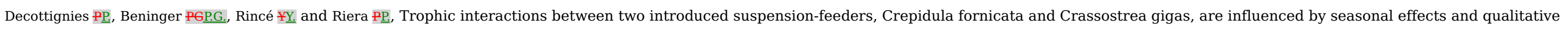
selection capacity, fExp Mar Biol Ecoij. Exp. Mar. Biol. Ecol. 342, 2007a, 231-241.

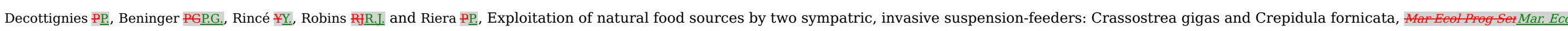
Prog. Ser. 334, 2007b, 179-192.

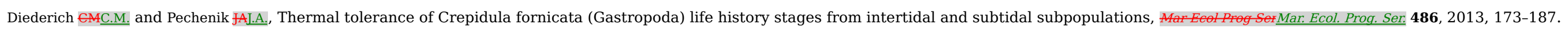

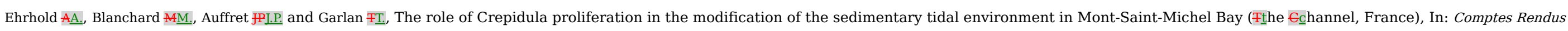
De L Academie Des Sciences Serie Ii Fascicule a-Sciences De La Terre Et Des Planetes, 327vol. 327, 1998, 583-588.

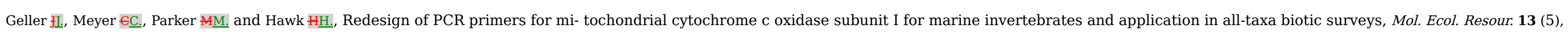
2013, 851-861.

Grall JI. and Hall-Spencer JMI.M., Problems facing maerl conservation in Brittany, Aquat. ConsertAquat. Conserv. 13 (1), 2003, 55-64.

Henry JQJ.Q. and Lyons ĐGD.C., Molluscan models: Crepidula fornicata, Eurrent Opinion in Geneties and DevelopmentCurr. Opin. Genet. Dev. 39, $2016,138-148$.

Huang

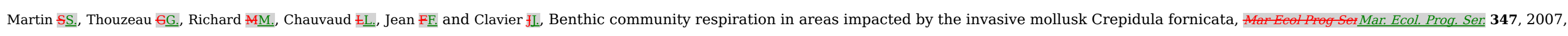
$51-60$.

McMillan NFN.F., Early records of Crepidula fornicata in English waters, Proc. Malac. Soc. London 23, 1938, 236.

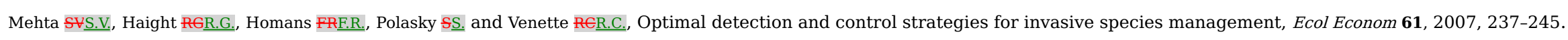

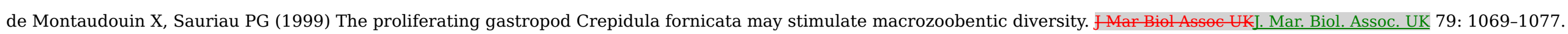

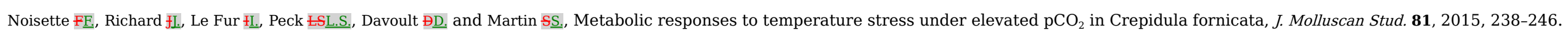

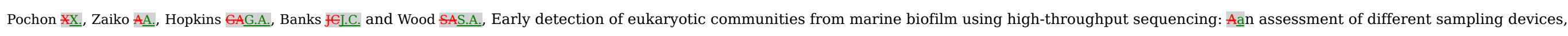

Biofouling 31, 2015, 241-251.

Rolán E. and Trigo J., Especies introducidas en Galicia: algunos nuevos datos, [Non indigenous species in Galicia: some new data], 47vol. 47, 2007, Noticiario Sociedad Española de M, 37-38.

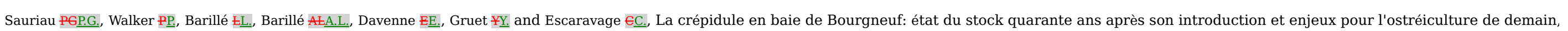

In: Chaussade J. and Guillaume J., (Eds.), Pêche et Aquaculture. Pour une exploitation durable des ressources vivantes de la mer et du littoral, 2006, Presses Universitaires de Rennes, 241-252.

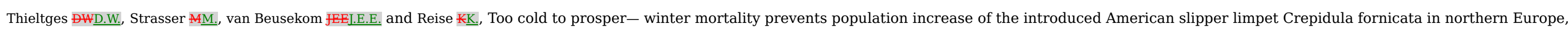
JExp Mar Biol Ecoil. Exp. Mar. Biol. Ecol. 311, 2004, 375-391.

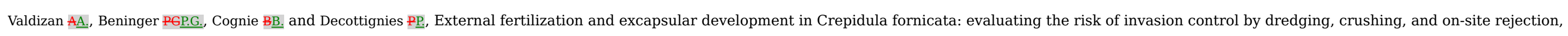




\section{Highlights}

- The first highly sensitive Gropidula fornicata specific marker was designed to detect the invasive limpet in environmental samples with a detection threshold of 0.66 .

- Six Spanish and French esturies in the South Bay of Biseay were monitorized to detect Erepidula fornicata employing eDNA water samples.

- The results confirmed the presenee of this invasive molluse in Galieir and Asturias, not in Santander, Bilba and Bayonne.

- Considering the potentially dangerous presenee of the invasive- G. fornicata in European coasts, we recommend the use of this novel molecular tool regularly

\section{Queries and Answers}

Query:

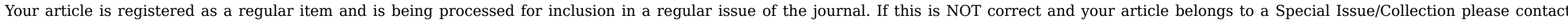
k.sivakolundu@elsevier.com immediately prior to returning your corrections.

Answer: it is a regular item

Query:

Please confirm that given names and surnames have been identified correctly and are presented in the desired order, and please carefully verify the spelling of all authors' names.

Answer: Hernández de Rojas is the complete surname of Alma

Query:

The author names have been tagged as given names and surnames (surnames are highlighted in teal color). Please confirm if they have been identified correctly

Answer: Hernández de Rojas is the complete surname of Alma.

Query:

Highlights should only consist of 125 characters per bullet point, including spaces. The highlights provided are too long; please edit them to meet the requirement.

Answer: The first highly sensitive $C$. fornicata specific marker was designed to detect this invasive limpet in environmental samples.

Six Spanish and French estuaries in the South Bay of Biscay were monitorized to detect Crepidula fornicata employing eDNA.

The results confirmed the presence of this invasive mollusc in Galicia and Asturias, not in Santander, Bilbao and Bayonne.

Spreading of the invasive C. fornicata in European coasts can be regularly monitored using this new molecular tool.

Query:

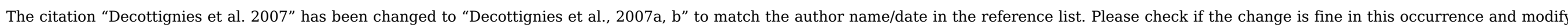
the subsequent occurrences, if necessary.

Answer: OK 


\section{Query:}

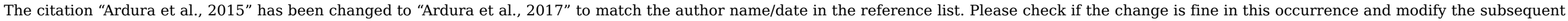
occurrences, if necessary.

Answer: OK

Query:

Have we correctly interpreted the following funding source(s) and country names you cited in your article: "University of Oviedo".

Answer: This work was funded by Asturias and Spanish governments through the grant IDI2018-000201 and the National Projects CGL2013-42415-R and CGL-2016-79209-R. 